\title{
Article \\ Authigenic Minerals of the Derbent and South Caspian Basins (Caspian Sea): Features of Forms, Distribution and Genesis under Conditions of Hydrogen Sulfide Contamination
}

\author{
Nina Kozina * D, Liudmila Reykhard and Olga Dara
}

check for

updates

Citation: Kozina, N.; Reykhard, L.; Dara, O. Authigenic Minerals of the Derbent and South Caspian Basins (Caspian Sea): Features of Forms, Distribution and Genesis under Conditions of Hydrogen Sulfide Contamination. Minerals 2022, 12, 87. https://doi.org/10.3390/ $\min 12010087$

Academic Editors:

Ana Romero-Freire and Hao Qiu

Received: 30 November 2021

Accepted: 7 January 2022

Published: 13 January 2022

Publisher's Note: MDPI stays neutral with regard to jurisdictional claims in published maps and institutional affiliations.

Copyright: (C) 2022 by the authors. Licensee MDPI, Basel, Switzerland. This article is an open access article distributed under the terms and conditions of the Creative Commons Attribution (CC BY) license (https:// creativecommons.org/licenses/by/ $4.0 /)$.
Shirshov Institute of Oceanology, Russian Academy of Sciences, 36, Nakhimovskiy Prospect, 117997 Moscow, Russia; mollusc@mail.ru (L.R.); olgadara@mail.ru (O.D.)

* Correspondence: kozina_nina@bk.ru

\begin{abstract}
This paper presents the results of complex lithological, mineralogical, and geochemical studies of bottom sediments of deep-water basins of the Caspian Sea (Derbent and South Caspian Basins) in areas contaminated by hydrogen sulfide. In the course of complex studies, numerous manifestations of authigenic mineral formation associated with the stage of early diagenesis have been established. Authigenic minerals belonging to the groups of sulfates (gypsum, barite), chlorides (halite), carbonates (calcite, low Mg-calcite; kutnohorite), and sulfides (framboidal pyrite), as well as their forms and composition, have been identified by a complex of analytical methods (X-ray diffractometry (XRD), scanning electron microscopy (SEM) with energy-dispersive X-ray spectroscopy (EDS); atomic absorption spectroscopy (AAS); coulometric titration (CT)); the nature of their distribution in bottom sediments has been assessed. Carbonates and sulfates are predominant authigenic minerals in the deep-water basins of the Caspian Sea. As a part of the study, differences have been established in the composition and distribution of associations of authigenic minerals in the bottom sediments in the deep-water basins. These are mineral associations characteristic of the uppermost part of the sediments (interval 0-3 cm) and underlying sediments. In the Derbent Basin, in sediments of the interval 3-46 cm, an authigenic association is formed from gypsum, calcite, magnesian calcite, siderite, and framboidal pyrite. An association of such authigenic minerals as gypsum and calcite is formed in sediments of the $0-3 \mathrm{~cm}$ interval. In the South Caspian Basin, in sediments of the interval 3-35 cm, an association of such authigenic minerals as gypsum, halite, calcite, magnesian calcite, and framboidal pyrite is formed. The association of such authigenic minerals as gypsum, halite, calcite, magnesian calcite, kutnohorite, and framboidal pyrite is characteristic of sediments of the 0-3 cm interval. We consider the aridity of the climate in the South Caspian region to be the main factor that determines the appearance of such differences in the uppermost layer of sediments of the basins. Judging by the change in the composition of authigenic associations, the aridity of the South Caspian increased sharply by the time of the accumulation of the upper layer of sediments (interval 0-3 cm). Taking into account lithological, mineralogical and geochemical data, the features of the processes of authigenic mineral formation in the deep-water basins of the Caspian Sea under conditions of hydrogen sulfide contamination have been determined. Analysis of the results obtained and published data on the conditions of sedimentation in the Caspian Sea showed that hydrogen sulfide contamination recorded in the bottom layer of the water column of the deep-water basins of the Caspian Sea may affect the formation of authigenic sulfides (framboidal pyrite), sulfates (gypsum), and carbonates (calcite and kutnohorite) associated with the activity of sulfate-reducing bacteria in reducing conditions.
\end{abstract}

Keywords: bottom sediments; modern sedimentation processes; mineralogy; geochemistry; authigenic minerals; hydrogen sulfide contamination; arid climate; Caspian Sea 


\section{Introduction}

Authigenic mineral formation attracts much attention from lithologists and marine geologists. Parageneses of authigenic minerals are considered the basis for diagnostics of sediment and rock formation stages. The essence of this process has been succinctly formulated by the American lithologist R. Fairbridge in 1985. Authigenic mineral formation (authigenesis) is a process in which minerals are formed in situ [1,2]. This term has been introduced by Kalkowsky [3]; nowadays, it is usually applied to sedimentary rocks in low-temperature conditions [2].

The formation of authigenic minerals in sedimentary basins occurs during sedimentation and subsequent diagenetic transformations of bottom sediments. Authigenesis occurs in the place of burial of sediments as a result of chemical, physicochemical, and biological (vital activity of organisms) processes [4-6]. Therefore, authigenic minerals are the main indicators of the environment, in which the formation of sedimentary deposits takes place, as well as of the processes of sediment transformation [7-12]. Authigenic minerals in the mineral composition of bottom sediments are an important genetic sign. The presence of some authigenic minerals indicates certain physicochemical characteristics of the water column in the sedimentation basin and subsequent diagenetic changes in sedimentary deposits. These changes include the behavior of various forms of chemical elements and the processes of microbial activity [12].

Authigenic minerals can be divided into organogenic minerals and chemogenic minerals [2]. Organogenic minerals are formed during the life of marine organisms (opal, aragonite, magnesian calcite, calcite, apatite, etc.) [2]. Chemogenic minerals are formed in a variety of ways. Minerals such as aragonite, dolomite, gypsum, halite, glauconite, and barite can be formed as a result of precipitation from true or colloidal solutions in sea or pore water [2]. Minerals of Fe-Mn nodules can form as a result of the precipitation of compounds from water and their redistribution in sediments during early diagenesis [2]. Hydrotroilite and pyrite are formed by the synthesis of compounds during diagenesis [2].

Thus, the formation of authigenic carbonates in the bottom sediments of the seas and oceans are considered in the works of Lein [13,14], Astakhova [15,16], Krylov [17,18], Derkachev [19], Kravchishina [10,20], et al. The manifestations of authigenic barite mineralization are considered in the works of Astakhova [21], Derkachev [22], et al.

The study of the complex process of authigenic mineral formation makes it possible to understand the history of the formation of sedimentary deposits from the stage of the mobilization of sedimentary material in the seas and oceans to its burial and transformation in diagenesis. Mineralogical research is a key group of methods used to study this process. In the Caspian Sea (Figure 1a), authigenic minerals have been studied rather poorly. Therefore, further research will significantly supplement the understanding of the history of sedimentation and general issues of the geological development of the Caspian Sea basin. Earlier, the processes of sedimentogenesis in the Caspian Sea, including the presence of authigenic minerals in the bottom sediments of the Caspian Sea, were presented with different generalizations in the works of L.S. Kulakova, L.I. Lebedev, Y.P. Khrustalev, and some others [23-26].

In the last few years, the researchers of the P.P. Shirshov Institute of Oceanology, Russian Academy of Sciences, have performed multidisciplinary research of oceanological, geological, and biochemical processes in the Caspian Sea [27-32]. As a result, new data on the distribution of sedimentary matter flows in the water column have been described [33-36]. In the works of Lukashin [33-36], the first data on the chemical composition of dispersed matter from sediment traps is presented. For the first time, seasonal changes in the fluxes of the biogenic triad were studied, along with the contribution of three main components of sedimentary matter $\left(\mathrm{SiO}_{2 a m o r p h}, \mathrm{CaCO}_{3}, \mathrm{OM}\right)$. It has been established that the annual variability of fluxes demonstrates its seasonal growth in spring and summer $[33,34]$. As a result, new knowledge has been gained about the biogeochemical processes occurring in the water column and in the near-bottom water layer [37-39]. Lein [32,39] presents the results of an investigation into microbial and biogeochemical processes at the water-sediment interface. 
The results of the microbiological and biogeochemical investigation demonstrated that, in spite of the absence of a connection with the ocean and other specific features, the Caspian Sea has the characteristics of a typical marine basin. The maximal sulfate reduction rate, the highest methane concentration, and the highest total microbial abundance (TMA) were observed in the sediment layer at $0.5-1.5 \mathrm{~cm}$ (up to $3.5 \mathrm{~cm}$ ), rather than in the warp. The fact that the most intensive biogeochemical activity was associated not with the warp, but with the underlying sediments made the processes of suspended matter transformation at the bottom water-sediment interface in the Caspian Sea different from those described in the process for the Russian Arctic seas. The microbial population of the sea bottom has the most important effect on sediment formation in the Caspian Sea. Microbial communities actively participate in all biogeochemical processes that take place in the near-bottom water and sediments [32,39]. As a result, new data have shown the distribution of micro- and macroelements, as well as rare-earth elements in surface bottom sediments [40-43]. Maslov and Gordeev [40-43] present an analysis of the distribution of rare and trace elements $(\mathrm{Zr}$, $\mathrm{Hf}, \mathrm{Th}, \mathrm{V}, \mathrm{Cr}, \mathrm{Co}, \mathrm{Ni}, \mathrm{Cu}, \mathrm{Sr}$, and $\mathrm{Ba}$ ) in modern bottom sediments of different subsystems of the Caspian Sea which, as well as their REE systematics, shows a geochemical set of features. The role of clusters, including fine-grained ones, coming from the mountain structures of the Caucasus and the Elburs, is already very small near the coasts, which is largely determined by both the influence of the marginal filter and the large-scale current cycles existing in the Caspian Sea $[42,43]$. As a result, the mineral composition of surface bottom sediments has already been described [8,9,44-46]. In the works of Kozina [8,9,44-46], the mineral composition of heavy and light subfractions of modern bottom sediments of the Caspian Sea have been studied. Terrigenous-mineralogical provinces have been identified. The main sources of detrital material have been established. The structural features and distribution pattern of framboidal pyrite in the bottom sediments of the South Caspian Basin have been studied. Authigenic minerals in the surface bottom sediments of the South Caspian Basin have been studied. Our study continues this research series and complements the current understanding of modern sedimentation processes and diagenesis in the Caspian Sea.

The Caspian Sea is the largest inland sea with no connection to the ocean. However, specific features of sedimentation processes here are similar to those observed in the sea [16]. The Caspian Sea occupies a deep depression, 27-28 m below the level of the World Ocean. The Basin area is $378,400 \mathrm{~km}^{2}[24,26]$. The Basin is a catchment basin of the river systems of the Russian Plain, Caucasus and Elbrus. The catchment basin is 3.6 million $\mathrm{km}^{2}$ [24]. The main rivers of the catchment basin are the Volga, Ural, Terek, Sulak, Samur, Kura, and Sefidrud. According to the nature of the natural situation and structure, the sea is divided into 3 parts: the Northern, Middle, and Southern Caspian, delimited by the Mangyshlak and Absheron thresholds. There is no river flow in the eastern part of the Middle and Southern Caspian. A characteristic feature of the catchment basin of the sea is its location in the humid, semiarid, and arid zones [24,26]. This feature preconditions the nature of the basin's supply by sedimentary material. Hydrological and sedimentation processes in the Caspian Sea are largely determined by the presence of deep-water basins, Derbent Basin (central part of the Sea), and South Caspian Basin (southern Caspian Sea) (Figure 1). The Derbent Basin is located in the center of the Middle Caspian Sea and is surrounded totally by a narrow shelf. Its maximum depth reaches $788 \mathrm{~m}[24,26]$. The extension of this basin is from northwest to southeast. A powerful cyclonic current dumps a huge amount of thin clastic material into this basin. The clastic material is washed away from the northern regions of the sea or comes with the waters of the Terek, Sulak, and Samur rivers. On the slopes of the Derbent Basin, traces of landslides and suspension flows are often found [24]. The formation of sedimentation in the Derbent Basin is determined by a number of factors: the influence of the powerful flow of the Volga River and the influence of Western Caucasian rivers. The South Caspian Basin occupies a major part of the Southern Caspian. The maximum depth of the basin is $1025 \mathrm{~m}$. The western side is cragged, and the eastern side rises gently and passes into a wide shelf area [24]. The bottom of the South 
Caspian Basin is complicated by mud volcanoes, as well as tectonic uplifts, which are expressed in the relief. Geologically, the South Caspian Basin has a number of features: its maximum depth is $1025 \mathrm{~m}$ and the bottom relief is uneven and complicated by numerous mud volcanoes; outcrops of active hydrothermal vents are located on the eastern coast of the South Caspian Basin [23-25]. In the South Caspian Basin, the sedimentation processes are preconditioned by their location in the arid zone $[34,35]$.
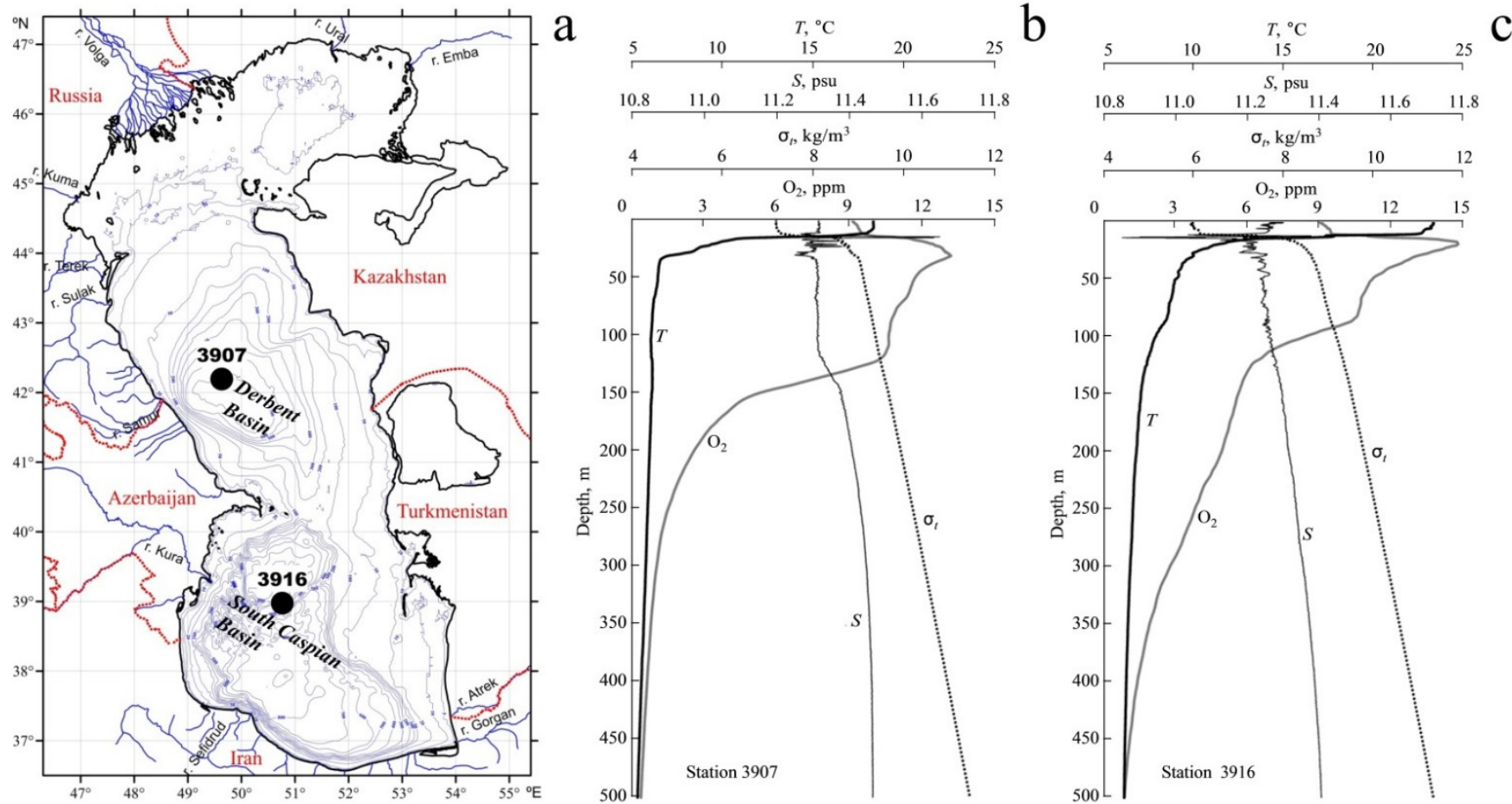

Figure 1. (a) Map-scheme of the research area and the location of the sampling of the Derbent (station 3907) and South Caspian (station 3916) Basins; (b,c) CTD-profiles of distribution of temperature $(T)$, salinity $(S)$, conventional density $(\delta t)$, and oxygen $\left(\mathrm{O}_{2}\right)$ in the water column of station 3907 and station 3916, modified according to [37].

Regard must be paid to the presence of hydrogen sulfide recorded in the near-bottom waters of the Derbent and South Caspian Basins since the 1930s [28,37,47]. This phenomenon was observed alongside significant fluctuations in sea level, recorded since the 1950s [48] and is associated with both climatic changes and anthropogenic factors [37].

In 2010-2012, after detailed hydrological and microbiological studies had been performed, the presence of dissolved hydrogen sulfide, a process of modern sulfate reduction, and, as a consequence, the anaerobic regime was described under conditions of stable temperature and hydrochemical stratification of the water column, at depths exceeding $650 \mathrm{~m}$ and $880 \mathrm{~m}$ in the Derbent and South Caspian Basins, respectively [37]. At the same time, the concentration of hydrogen sulfide increases from the upper limit of its detection to the near-bottom water layer, from 20 to $120 \mu \mathrm{L} / \mathrm{L}$ in the Derbent Basin and from 60 to $240 \mu \mathrm{L} / \mathrm{L}$ in the South Caspian Basin (Figure 1). Active processes of bacterial sulfate reduction have also been recorded in the surface layer of bottom sediments $(0.0-1.5 \mathrm{~cm})$ [37].

This research continues a series of studies devoted to the issue of authigenic mineral formation in the bottom sediments in areas of hydrogen sulfide contamination of the enclosed and marginal seas of Russia [8,9,49-52]. Here, we aim to study the features of the processes of authigenic mineral formation in the bottom sediments of the deep-water basins of the Caspian Sea under conditions of hydrogen sulfide contamination. 


\section{Materials and Methods}

\subsection{Materials}

The material was collected during the 39th cruise of the R/V Rift in 2012 [28,32,33].

Bottom sediments were sampled in the Derbent Basin at a $720 \mathrm{~m}$ depth (station no. 3907; $42^{\circ} 11.680^{\prime} \mathrm{N}, 49^{\circ} 37.978^{\prime} \mathrm{E}$ ) and in the South Caspian Basin at a $1000 \mathrm{~m}$ depth (station no. 3916; $38^{\circ} 58.528^{\prime} \mathrm{N}, 50^{\circ} 45.738^{\prime} \mathrm{E}$ ) (Figure 1a). Sampling was carried out using a KUM multicorer MiniMUC (Germany). This sampling method allowed one to preserve the boundary layer between the water column and bottom sediments, i.e., the upper flocculated layer (fluffy layer), with no disturbance.

Bottom sediments were sampled by a core in the Derbent Basin $(46 \mathrm{~cm}$ long, $10 \mathrm{~cm}$ diameter) and in the South Caspian Basin ( $35 \mathrm{~cm}$ long, $10 \mathrm{~cm}$ diameter). The sediment core was subdivided with different discreteness, starting at $0.5 \mathrm{~cm}$ sections (upper part of the core) and increasing up to $5.0 \mathrm{~cm}$ sections (the deepest sediment layers). The lithological types of bottom sediments were distinguished according to [53].

\subsection{Methods}

Mineralogical and geochemical studies of bottom sediments were carried out in the P.P. Shirshov Institute of Oceanology, Russian Academy of Sciences (Moscow, Russia). The mineral composition was analyzed on a D8 ADVANCE X-ray diffractometer (Bruker AXC, Karlsruhe, Germany). The identification of clay minerals and the determination of their quantitative ratios was carried out according to widespread methods [54-57]. In accordance with these methods, oriented air-dry preparations were prepared from a suspension of the clay fraction separated from the sample in distilled water. Further, the preparations were saturated with ethylene glycol (for diagnostics of minerals of the smectite group, as well as mixed-layered formations with swelling layers). Then, the preparations were warmed up at $550{ }^{\circ} \mathrm{C}$ (for the diagnosis of kaolinite and chlorite). The technique was applied in full or reduced, as required. The visualization of microscopic components and analysis of their chemical composition were performed by a Scanning Electron Microscope Vega 3 Tescan (TESCAN, Brno, Czech Republic) with an X-ray spectral microanalyzer INCA Energy (OXFORD Instruments, High Wycombe, UK), and Scanning Electron Microscope Phenom ProX G6 with an integrated EDS system (Thermo Scientific Phenom, Eindhoven, Netherlands). The total content of micro- and macroelements in bottom sediments was determined by the method of flame Atomic Absorption Spectroscopy in an acetylene-air flame in a Kvant-2A Spectrophotometer (Cortec, Moscow, Russia). The content of total, organic, and carbonate carbon was determined by coulometric titration in an AN-7529 carbon analyzer (Akvilon, Podolsk, Russia).

\section{Results}

\subsection{Lithological, Mineralogical, and Geochemical Characteristics of Bottom Sediments of the Derbent Basin}

The bottom sediments in the central part of the Derbent Basin (station no. 3907; sediment core length of $46 \mathrm{~cm}$ ) are represented by alternating pelitic silts, mainly weakly calcareous (with massive and microlayer texture, expressed in the alternation of thin layers of unoxidized and oxidized silts) and hydrotroilite layers (up to $1 \mathrm{~mm}$ thick). The top layer of sediments $(0.0-1.0 \mathrm{~cm})$ is represented by a reduced black flocculent silty deposit. A strong smell of hydrogen sulfide is present in bottom sediments down to a depth of $10 \mathrm{~cm}$.

According to microscopic studies, supported by the results of $\mathrm{XRD}$, the mineral composition of the bottom sediments in the Derbent Basin is represented mainly by quartz (18-29\%), feldspars (albite, up to 15\%; potassium feldspar, up to $11 \%$ ), and clay minerals (illite, up to $17 \%$; kaolinite, up to $10 \%$; chlorite, up to $16 \%$; and smectite, up to $1 \%$ ) (Table 1 ). The sediments have a high content of authigenic minerals of the sulfate groups (gypsum, up to $28 \%$ ), carbonates (calcite, up to $8 \%$; magnesian calcite, up to $3 \%$; aragonite, up to $2 \%$; siderite and dolomite, up to $1 \%$ each), and sulfides (pyrite, up to $3 \%$ ) (Table 1). 
Table 1. Mineral composition in bottom sediments of the Derbent and South Caspian Basins.

\begin{tabular}{|c|c|c|c|c|c|c|c|c|c|c|c|c|c|c|c|c|}
\hline $\begin{array}{c}\text { Depth, } \\
\text { cm }\end{array}$ & $\begin{array}{l}\text { Qz, } \\
\%\end{array}$ & $\begin{array}{c}\mathrm{Ab}, \\
\%\end{array}$ & $\begin{array}{c}\text { K-fsp, } \\
\%\end{array}$ & $\begin{array}{c}\text { Chl, } \\
\%\end{array}$ & $\begin{array}{c}\text { Kln, } \\
\%\end{array}$ & $\begin{array}{l}\text { Ilt, } \\
\%\end{array}$ & $\begin{array}{c}\text { Sme, } \\
\%\end{array}$ & $\begin{array}{l}\text { Gp, } \\
\%\end{array}$ & $\begin{array}{l}\mathrm{Hl}, \\
\%\end{array}$ & $\begin{array}{c}\text { Cal, } \\
\%\end{array}$ & $\underset{\%}{\text { Mg-Cal, }}$ & $\begin{array}{c}\text { Dol, } \\
\%\end{array}$ & $\begin{array}{l}\text { Sd, } \\
\%\end{array}$ & $\underset{\%}{\text { Arg, }}$ & $\underset{\%}{\text { Kut, }}$ & $\begin{array}{l}\text { Py, } \\
\%\end{array}$ \\
\hline & \multicolumn{16}{|c|}{ Derbent Basin (СТ. 3907) } \\
\hline $0-0.5$ & 18 & 13 & 10 & 15 & 10 & 16 & 1 & 11 & n.d. & 5 & n.d. & 1 & n.d. & n.d. & n.d. & n.d. \\
\hline $1.5-2$ & 24 & 14 & 8 & 16 & 9 & 17 & 1 & 7 & n.d. & 4 & n.d. & n.d. & n.d. & n.d. & n.d. & n.d. \\
\hline $3.5-4$ & 25 & 15 & 11 & 12 & 7 & 16 & 1 & 5 & n.d. & 5 & n.d. & 1 & 1 & n.d. & n.d. & 1 \\
\hline $6-7$ & 20 & 12 & 8 & 10 & 6 & 14 & 1 & 20 & n.d. & 6 & 1 & n.d. & n.d. & n.d. & n.d. & 2 \\
\hline $9-10$ & 29 & 14 & 8 & 9 & 6 & 13 & 1 & 4 & n.d. & 8 & 3 & 1 & 1 & 2 & n.d. & 1 \\
\hline $12-13$ & 18 & 15 & 9 & 9 & 7 & 16 & 1 & 13 & n.d. & 7 & 2 & n.d. & 1 & 1 & n.d. & 1 \\
\hline $15-17$ & 18 & 12 & 9 & 10 & 6 & 14 & 1 & 19 & n.d. & 5 & 3 & n.d. & n.d. & 1 & n.d. & 2 \\
\hline $21-23$ & 20 & 13 & 8 & 11 & 6 & 15 & 1 & 13 & n.d. & 7 & 3 & n.d. & n.d. & 2 & n.d. & 1 \\
\hline 29-31 & 17 & 12 & 7 & 9 & 5 & 12 & 1 & 28 & n.d. & 6 & 2 & 1 & n.d. & n.d. & n.d. & 1 \\
\hline $37-39$ & 28 & 15 & 7 & 11 & 7 & 14 & 1 & 4 & n.d. & 8 & 2 & n.d. & n.d. & 2 & n.d. & 1 \\
\hline \multirow[t]{2}{*}{$44-46$} & 25 & 15 & 8 & 10 & 7 & 13 & 1 & 8 & n.d. & 8 & 2 & n.d. & n.d. & n.d. & n.d. & 3 \\
\hline & \multicolumn{16}{|c|}{ South Caspian Basin (Ст. 3916) } \\
\hline $0-0.5$ & 17 & 11 & 10 & 10 & 6 & 13 & tr. & 7 & 16 & 6 & 1 & n.d. & n.d. & n.d. & 2 & 1 \\
\hline $0.5-1$ & 14 & 13 & n.d. & 11 & 7 & 15 & tr. & 22 & 6 & 6 & n.d. & n.d. & n.d. & n.d. & 6 & n.d. \\
\hline $1-1.5$ & 15 & 10 & 6 & 8 & 6 & 20 & tr. & 25 & 3 & 4 & 6 & n.d. & n.d. & n.d. & 2 & n.d. \\
\hline $2.5-3$ & 25 & 14 & 7 & 10 & 6 & 18 & tr. & 3 & 1 & 7 & 4 & n.d. & n.d. & n.d. & 2 & n.d. \\
\hline $4-4.5$ & 26 & 13 & 7 & 10 & 6 & 21 & 0.3 & 3 & 1 & 7 & 3 & n.d. & n.d. & 2 & n.d. & 1 \\
\hline $6-7$ & 22 & 14 & 7 & 14 & 7 & 17 & 0.4 & 2 & 1 & 7 & 4 & n.d. & n.d. & 1 & n.d. & 4 \\
\hline 9-10 & 26 & 13 & 7 & 10 & 6 & 16 & 0.4 & 3 & 1 & 7 & 9 & n.d. & n.d. & n.d. & n.d. & 2 \\
\hline $12-13$ & 23 & 14 & 8 & 10 & 6 & 17 & 0.4 & 2 & 1 & 8 & 10 & n.d. & n.d. & n.d. & n.d. & 1 \\
\hline $16-17$ & 28 & 14 & 8 & 8 & 8 & 12 & 0.4 & 2 & 1 & 8 & 9 & n.d. & n.d. & n.d. & n.d. & 2 \\
\hline $20-22$ & 25 & 13 & 6 & 13 & 7 & 17 & 0.5 & 1 & 2 & 7 & 8 & n.d. & n.d. & n.d. & n.d. & n.d. \\
\hline $26-28$ & 22 & 12 & 15 & 11 & 6 & 16 & 0.3 & n.d. & 1 & 7 & 9 & n.d. & n.d. & n.d. & n.d. & 1 \\
\hline $33-35$ & 29 & 11 & 8 & 6 & 4 & 10 & tr. & 8 & 1 & 8 & 11 & n.d. & n.d. & 1 & n.d. & 3 \\
\hline
\end{tabular}

Gypsum was found throughout the entire core in the pelitic sediments of the Derbent Basin (station no. 3907). The gypsum content varies at $4-28 \%$ without a definite pattern (Table 1). Gypsum is present as crystals of hexagonal and prismatic shapes, as well as their aggregates (Figure 2a,b).

In the deposits of the Derbent Basin, carbonate minerals are found along with the entire core, but mineral associations differ in different layers. In particular, calcite is present in all studied layers. An uneven increase in the content of calcite (from 5 to $8 \%$ ) and the appearance of Mg-calcite (1-3\%) are recorded in the sediments from the $6.0 \mathrm{~cm}$ depth and below (Table 1). Calcite occurs as aggregate accumulations of microcrystals with a corroded surface (Figure 2c). Mg-calcite is presented as prismatic crystals with perfect cleavage and crystalline aggregates with traces of severe corrosion on the cleavage (Figure 2d) and crystalline aggregates with traces of severe corrosion on the cleavage planes (Figure 2e). Dolomite, siderite, and aragonite are distributed unevenly along with the entire core; their content does not exceed 2\% (Table 1). Siderite is found only in the upper part of the column (Table 1). Opposite to it, aragonite is absent in the upper part of the column and is found only at a depth of $9.0-10.0 \mathrm{~cm}$. Dolomite is presented by rare prismatic crystals, siderite, by micro globular aggregates (Figure 2f). Aragonite was not detected by SEM.

The content of pyrite varies from 1 to $3 \%$ throughout the entire core. The pyrite presents as framboids and crystallites, which develop both in zones enriched with detritus of diatom frustules and in the pore space of pelitic sediments (Figure $2 g-j$ ). The framboids have a spherical shape (up to $12-15 \mu \mathrm{m}$ in diameter). They form various crystallites-irregular, polyhedral, and globular. 

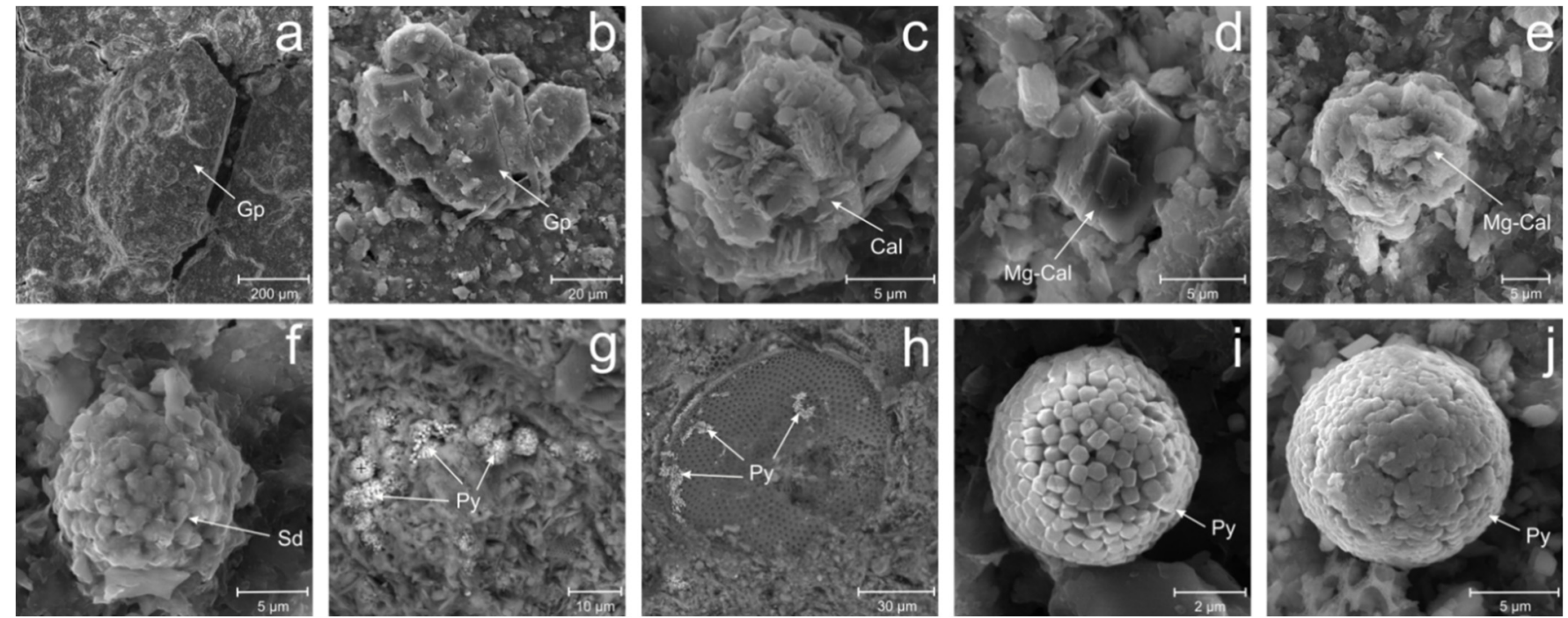

Figure 2. Authigenic minerals in bottom sediments of the Derbent Basin (SEM Images): (a) hexagonal gypsum crystal; (b) an aggregate of gypsum crystals; (c) aggregate of calcite crystals with traces of corrosion; (d) a crystal of Mg-calcite; (e) highly corroded aggregate of Mg-calcite crystals; (f) siderite microglobular aggregate; (g) cluster of pyrite framboids and crystallites; (h) pyrite crystallites on the surface of the centric diatom frustula; (i) pyrite framboid of polygonal crystallites; (j) pyrite framboid of irregular and globular crystallites.

Geochemical analyses evidence that the studied bottom sediments in the Derbent Basin are strongly but unevenly enriched in organic carbon and $\mathrm{Fe}_{(\text {total }}$ (Figure 3).

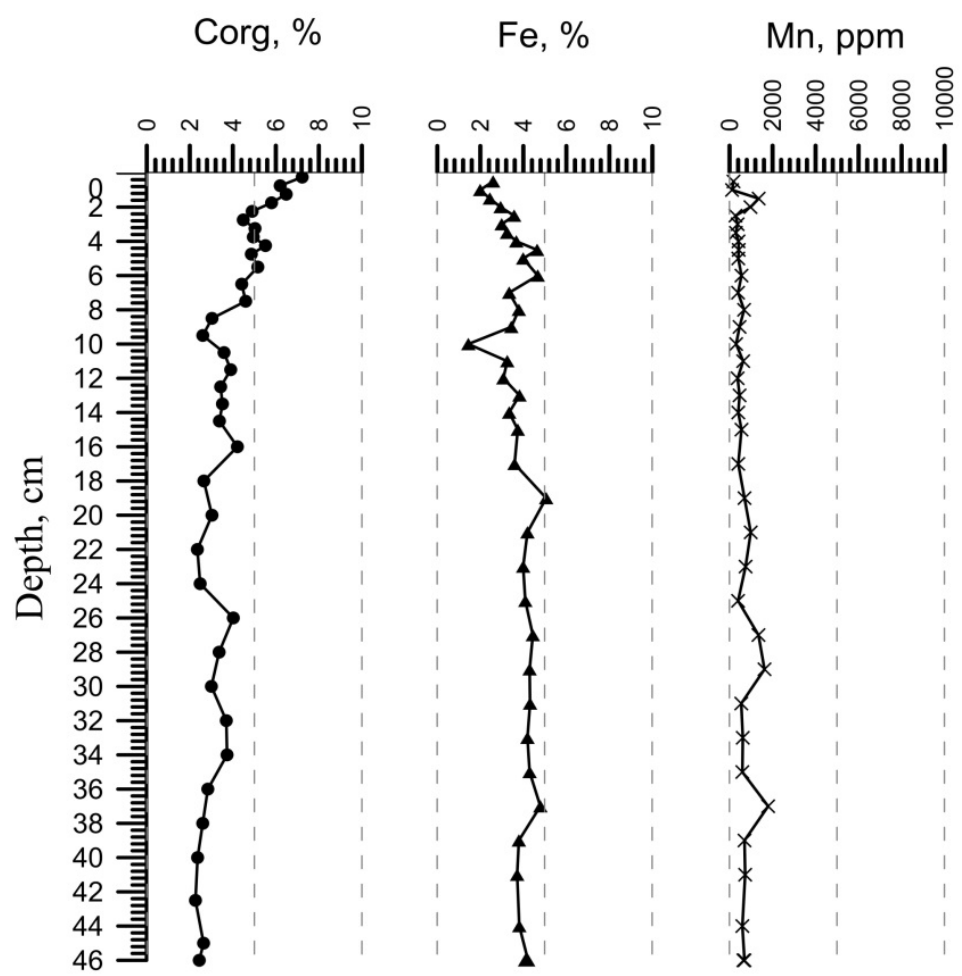

Figure 3. Distribution of Corg, Fe, Mn in the bottom sediments of the Derbent Basin (st. 3907).

$\mathrm{Fe}_{\text {(total) }}$ content varies from $1.45 \%$ to $5.07 \%$ through the entire core, tending to increase unevenly from the upper layers down to the lowest, except the $9.0-10.0 \mathrm{~cm}$ layer, where iron content decreases and reaches a minimum value of $1.45 \%$ (Figure 3 ). 
The upper layers of bottom sediments are highly enriched in organic carbon, $\mathrm{C}_{\text {org }}$ (Figure 3). In the silty deposit, the organic carbon content reaches its maximum value of $7.2 \%$; down the column, it decreases down to a minimum value of $2.2 \%$ (41-44 cm depth).

\subsection{Lithological, Mineralogical, and Geochemical Characteristics of the South Caspian Basin}

Bottom sediments of the central part of the South Caspian Basin (station no. 3916; core length of $35 \mathrm{~cm}$ ) are represented by alternating pelitic sediments with an insignificant content of sandy-silty admixtures, mostly weakly calcareous, with a micro layered and porous-cavernous texture, saturated with hydrotroilite to varying degrees by smears, concretions, and thin layers. The upper layer of bottom sediment $(0.0-0.5 \mathrm{~cm})$ is represented by reduced silty deposits, presented as black and green flakes. A strong smell of hydrogen sulfide is present in bottom sediments down to a depth of $8 \mathrm{~cm}$.

According to microscopic studies, supported by the XRD method, the mineral composition of bottom sediments is represented by quartz (14-29\%), feldspars (albite, up to $14 \%$; feldspar, up to $15 \%$ ), and clay minerals (illite, up to $21 \%$; kaolinite, up to $8 \%$; chlorite, up to $14 \%$; and smectite, up to $0.5 \%$ ) in various ratios [8] (Table 1 ).

A high content of authigenic minerals belonging to the groups of sulfates, carbonates, and sulfides, such as gypsum (up to $25 \%$ ), halite (up to $16 \%$ ) calcite (up to $8 \%$ ), magnesian calcite (up to $11 \%$ ), kutnohorite (up to $6 \%$ ), and pyrite (up to $4 \%$ ) is observed in the core (Table 1).

Gypsum is found in the pelitic sediments of the South Caspian Basin along the entire length of the core, with a maximum content of $7-25 \%$ in the uppermost layer at $0.0-1.5 \mathrm{~cm}$. Gypsum is present in the sediments as radial-radiant aggregates (rosettes), hexagonal gypsum crystals, intergrowths of prismatic crystals, prismatic single crystals with perfect cleavage, fibrous aggregates, and crystalline masses [9] (Figure 4a-d). The size of gypsum crystals ranges from $1-3 \mu \mathrm{m}$ to $50 \mu \mathrm{m}$.

Barite, another authigenic mineral of the sulfate group, is presented by single inclusions of micro aggregates of lamellar crystals in the deposits of the South Caspian Basin. Barite was detected only by SEM+EDS (Figure 4e).

Halite was found in the form of aggregates of irregularly shaped crystals (Figure 4f).

Carbonate minerals occur in sediments along with the entire core; they are represented by calcite, Mg-calcite, aragonite, and kutnohorite (Table 1). The contents of calcite and $\mathrm{Mg}$-calcite increase unevenly from a $2.5 \mathrm{~cm}$ depth and deeper down to the end of the core.

Calcite is one of the predominant minerals of the carbonate group in the sediments of the South Caspian Basin. The calcite content in the sediments of the uppermost part of the core $(0.0-2.5 \mathrm{~cm})$ ranges from 4 to $6 \%$ and constitutes $7-8 \%$ from a $2.5 \mathrm{~cm}$ depth and below (Table 1). Calcite occurs in bottom sediments by parallel-columnar aggregates, continuous fibrous masses, crystals with perfect cleavage along the rhombohedron, microglobular calcite aggregate, and aggregate accumulations of microcrystals (Figure 4g,h) [9]. The content of $\mathrm{Mg}$-calcite varies from 1 to $11 \%$ (Table 1 ). Mg-calcite is presented as prismatic crystals and lamellar aggregates. Dolomite is found as single rhombohedral crystals (Figure 4i).

Aragonite was found only by the XRD method in a very insignificant amount (1-2\%) in the upper and lower parts of the core (Table 1).

Kutnohorite was detected in the uppermost layer of the sediment $(0.0-3.0 \mathrm{~cm})$, where its content varies from 2 to $6 \%$, reaching a maximum in the layer of $0.5-1.0 \mathrm{~cm}$ (Table 1 ). Kutnohorite is represented by numerous clusters of irregularly shaped microcrystal aggregates (Figure 4j) $[8,9,44]$. 

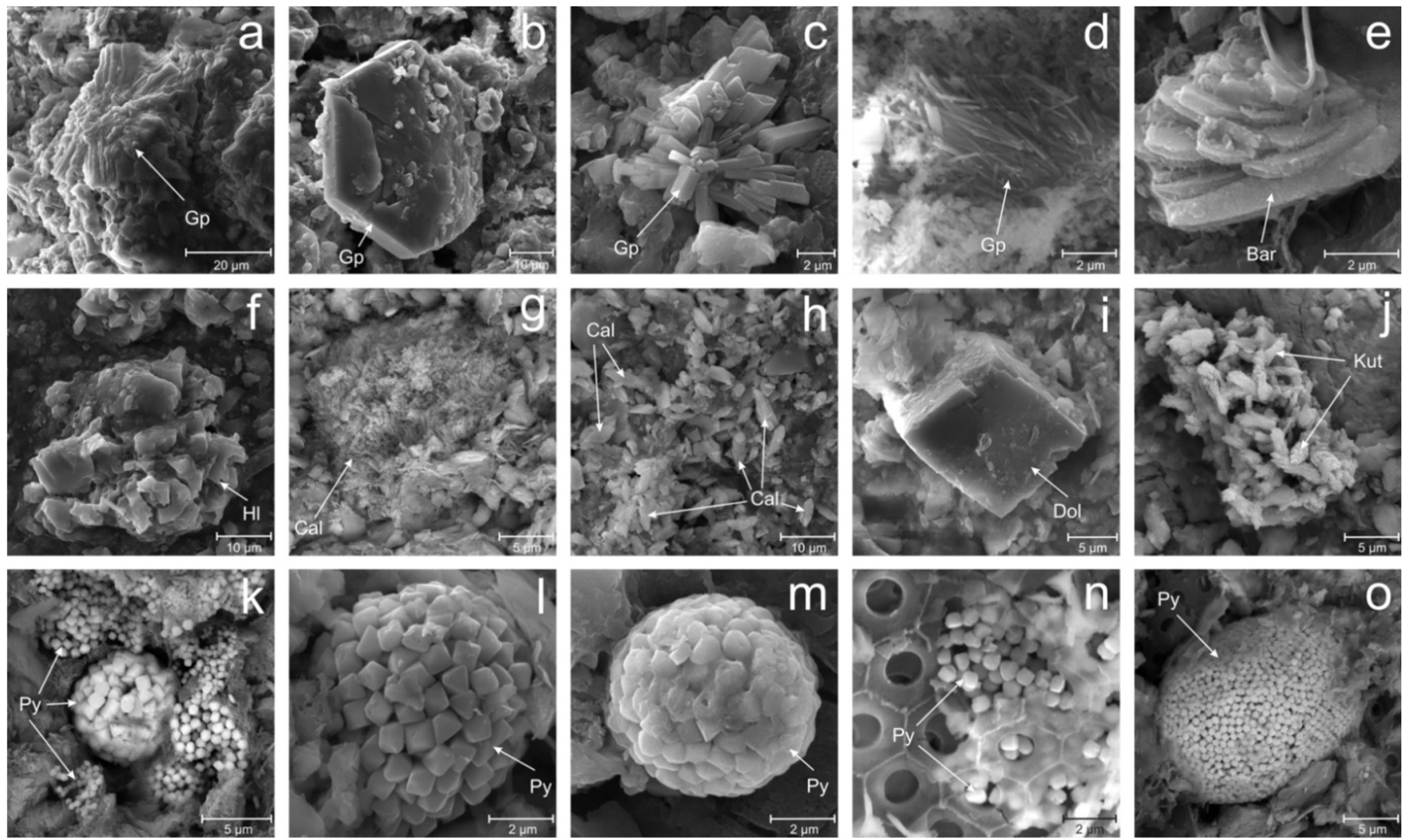

Figure 4. Authigenic minerals in bottom sediments of the South Caspian Basin (SEM Images): (a) gypsum radial-radiant aggregate of the "gypsum rose" type; (b) a hexagonal gypsum crystal; (c) an aggregate of gypsum long-prismatic crystals; (d) fibrous gypsum aggregate; (e) an aggregate of barite crystals; (f) an aggregate of halite crystals; (g) microglobular calcite aggregate; (h) cluster of calcite microcrystals; (i) rhombohedral dolomite crystal; (j) an aggregate of kutnohorite microcrystals; (k) pyrite framboid and crystallite cluster; (1) pyrite framboid from octahedral crystallites; (m) pyrite framboid of irregular crystallites; (n) pyrite crystallites within the diatom frustula; (o) irregular pyrite framboid.

The content of sulfides (represented by pyrite) varies from 1 to $4 \%$ without a definite pattern. It is important to note that pyrite has already been found in the Caspian Sea and its maximum content is observed at a depth of $6.0-7.0 \mathrm{~cm}$. It was established that pyrite is present in the form of framboids-spherical aggregates of a complex structure, consisting of crystallites, as well as in the form of individual crystallites or their disordered accumulations, which may be the result of the mechanical destruction of framboids (Figure $4 \mathrm{k}-\mathrm{O}$ ). As a rule, framboids have a spherical shape, up to $20 \mu \mathrm{m}$ in diameter. Framboids of irregular shape (possibly deformed), up to $30 \mu \mathrm{m} \times 40 \mu \mathrm{m}$ in size, were also found. Crystallites have different shapes (octahedral, globular, and irregular) and are randomly located in the structure of framboids. It is important to note that crystallites, even within the same framboid, may have different shapes. Framboidal pyrite forms both on the surface of plant attrite and frustules of diatoms and in the intergranular pore space of pelitic deposits [8].

A very high content of halite $(16 \%)$ has been found in the uppermost part of the studied bottom sediments. Down the core, the halite content sharply decreases, constituting only $1-2 \%$ below the layer of $2.5-3.0 \mathrm{~cm}$ (Table 1 ).

According to geochemical analyses of bottom sediments of the South Caspian Basin,

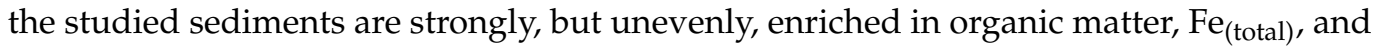
manganese [8,9] (Figure 5). 


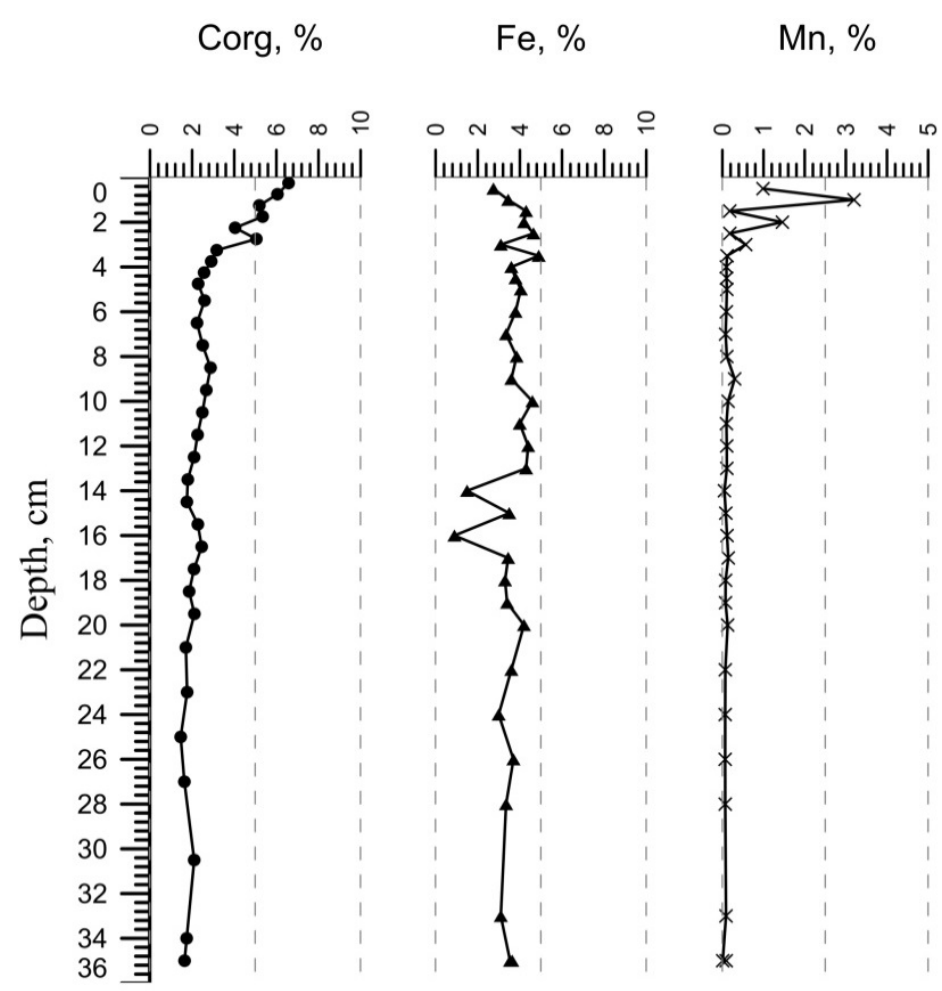

Figure 5. Distribution of Corg, Fe, and Mn in the bottom sediments of the South Caspian Basin (st. 3916).

$\mathrm{Fe}_{(\text {total })}$ content varies greatly over the entire core without any regularity. The minimum iron content $(0.9 \%)$ is observed in the $15.0-16.0 \mathrm{~cm}$ layer, and the maximum $(4.9 \%)$ in the upper part of the core $(3.0-3.5 \mathrm{~cm})$ (Figure 5).

The upper layers of bottom sediments are highly enriched in organic carbon. In the silty deposit layer, the $\mathrm{C}_{\text {org }}$ content reaches a maximum of $6.5 \%$. Down the core, it unevenly decreases to a minimum of $1.4 \%$ at a $24.0-26.0 \mathrm{~cm}$ depth.

The maximum manganese content is typical for the fluffy layer and the upper layers of sediments, amounting to $1.4 \%(1.5-2.0 \mathrm{~cm})$ and $3.2 \%(0.5-1.0 \mathrm{~cm})$. The manganese content drops sharply down to $1830 \mathrm{ppm}$ from a $2.0 \mathrm{~cm}$ depth $[8,9]$.

\section{Discussion}

4.1. Authigenic Minerals and Features of Their Formation in the Bottom Sediments of the Derbent Basin and the South Caspian Basin

In the bottom sediments of the Derbent and South Caspian basins authigenic mineral formation is manifested by authigenic minerals of the sulfate group (gypsum, barite), carbonate group (calcite, $\mathrm{Mg}$-calcite, kutnohorite, dolomite, siderite, and aragonite), chloride group (halite), and sulfide group (framboidal pyrite). Gypsum, calcite, Mg-calcite, and pyrite are the most common authigenic minerals in the Holocene deposits of the studied areas. The presence of these minerals both in the upper and in deeper layers of the sedimentary strata is associated with a combination of special geological, hydrological, and biogeochemical conditions prevailing in these areas [32,33,37,39,47].

In the study areas, authigenic minerals are presented in various forms. Radial-radiant crystalline aggregates, crystals of various habitus and their aggregates are characteristic forms for minerals of the sulfate group (gypsum, barite). Carbonates (calcite, Mg-calcite, kutnohorite, and siderite) are presented as crystals, microcrystalline aggregates, fibrous masses, and globular forms. Sulfides (pyrite) are presented as crystallites and their aggregates (framboids).

Gypsum is an aqueous calcium sulfate. In all studied layers of bottom sediments of the Derbent and South Caspian basins, authigenic precipitation of gypsum is observed. 
The formation of gypsum in the bottom sediments of the deep-water basins of the Caspian Sea in areas of hydrogen sulfide contamination presumably occurs in two ways, similar to the formation of sulfates in the sediments of the seas and oceans [2,5]. In particular, the first way is chemogenic, i.e., gypsum is formed simultaneously with the host rocks as a result of chemical precipitation from sulfate-rich aqueous solutions. The second way is biochemical, whereby the content of organic matter and carbonates in sediments is high and accompanied by the activity of sulfate-reducing bacteria. The sulfur cycle of marine sediments is primarily driven by the dissimilatory sulfate reduction to sulfide by anaerobic microorganisms $[58,59]$. Sulfate-reducing bacteria are anaerobic microorganisms that use sulfate as the final electron acceptor in the oxidation of organic compounds or molecular hydrogen. Under anaerobic conditions, sulfate reducers carry out terminal destruction of organic compounds and produce hydrogen sulfide. Sulfate-reducing bacteria include representatives of Desulfovibrio desulfurcans and Desulfotomaculum [60]. At present, there are very few data on sulfate reducers in the bottom sediments of the deep-water zones of the Caspian Sea. However, there is evidence that sulfate-reducing bacteria from the Desulfobacterales family have been identified in the upper part of the bottom sediments of the southern part of the Caspian Sea [61]. Sulfate-reducing bacteria can contribute to the formation of various minerals, mainly sulfides (pyrite, hydrotroilite). It has been established that the biogenic mechanisms of mineral formation in global biogeochemical cycles by bacteria-induced mineral precipitation, including sulfate-reducing bacteria in the sulfur cycle, are very diverse [62].

In the South Caspian Basin, the maximum gypsum content is observed in the upper layers of the sediment. High concentrations of gypsum in the upper layers are most likely associated with the peculiarities of sedimentation processes in an arid climate [5,9] and the chemogenic formation of gypsum in sediments from pore solutions saturated with sulfur and calcium, as well as with biogeochemical processes occurring in bottom sediments of the South Caspian Basin under conditions of hydrogen sulfide contamination [9,39]. In the Derbent Basin, high gypsum concentrations are observed in all studied layers of bottom sediments.

Barite is found only in the deposits of the South Caspian Basin by single microcrystalline aggregates. Based on the appearance of barite crystals, which differs from the appearance of biogenic marine barite [63], the composition of the authigenic mineral association $[49,50,64]$, and the conditions of sedimentation in the South Caspian Basin, it may be assumed that the origin of barite is early diagenetic, taking place during crystallization of pore solutions supersaturated with $\mathrm{S}$ and $\mathrm{Ba}[9,50]$.

High halite contents, found only in the upper layer of bottom sediments of the South Caspian Basin, are possibly related to sedimentation under arid conditions typical for this zone $[24,26]$.

Carbonate minerals are the most widespread authigenic minerals in the sediments of the deep-water basins of the Caspian Sea. Calcite and Mg-calcite predominate in the sediments; dolomite, siderite, kutnohorite, and aragonite are found in insignificant quantities. A greater variety of forms of authigenic calcite is observed in the deposits of the South Caspian Basin compared with the Derbent Basin.

In bottom sediments, the formation of authigenic calcite from solutions, which are supersaturated with calcium carbonate, occurs during the decomposition of organic matter by bacteria. The latter is accompanied by the formation of $\mathrm{CO}_{2}$, hydrogen sulfide, etc. [2,5]. The formation of authigenic carbonate minerals in the sediments of the Derbent and South Caspian basins is greatly influenced by several factors, such as the chemical composition of pore waters, reducing conditions, abundant content of organic matter in sediments, and arid climate. As a result of the interaction of the constituent components of the sediment with pore waters and dissolved organic matter, processes of authigenic formation of carbonate minerals occur with the active influence of sulfate-reducing bacteria.

The Mg-calcite content in the deposits of the South Caspian Basin is several times higher than that of the Derbent Basin (Table 1). The amount of Mg-calcite in the sediments 
of the South Caspian Basin increases with depth. No Mg-calcite is found in the sediments of the Derbent Basin in the upper layers of the sediment $(0.0-6.0 \mathrm{~cm})$.

Authigenic siderite in the Derbent Basin is formed under reduced conditions with an abundant content of organic matter and the active participation of sulfate-reducing bacteria. In a reducing environment, when carbon dioxide reacts with silicate minerals, iron bicarbonates are formed; they transform into siderite during further stages of diagenesis, and further into pyrite in the presence of hydrogen sulfide and hydrogen sulfide bacteria. It is important to note that siderite is found in the sediments of the Derbent Basin. Siderite is found in the layers where the formation of framboidal pyrite is recorded. Siderite has not been recorded at all in the sediments of the South Caspian Basin.

Aragonite was found only by the XRD method as an insignificant rare impurity $(1-2 \%)$ in the mineral composition of the studied bottom sediments. No crystalline forms were found to identify this mineral by microscopic methods. Therefore, it may be assumed that aragonite has a biogenic origin and is most likely present in single biogenic detrital components (for example, shell detritus) in the bottom sediments of the South Caspian Basin, as noted in $[8,9]$.

Kutnohorite is found only in the surface layer of bottom sediments of the South Caspian Basin $(0.0-3.0 \mathrm{~cm})$ and should be attributed to authigenic minerals in the early stage of diagenesis. Pore water supersaturated with $\mathrm{Ca}^{2+}$ and $\mathrm{Mn}^{2+}$ may be the source of these cations; carbon dioxide, which is a part of kutnohorite, is formed during microbial decomposition of organic matter in sediments [44]. Manganese ores, which are widespread within the Greater Caucasus, and the waters of the Cheleken-Boyadag hydrothermal system enriched in manganese, may also supply Mn to the South Caspian Basin [33,34,44].

Dolomite is found in the deposits of the Derbent Basin at an insignificant admixture $(1 \%)$, and it is absent in the sediments of the South Caspian Basin. According to some researchers [33,35], dolomite is transported here with aeolian material.

Framboidal pyrite is a widespread authigenic mineral in modern bottom sediments of the Derbent and South Caspian basins. It is present both in deep layers of the sedimentary strata and in the very surface layer of bottom sediments, which is associated with a combination of special geological, hydrological, and geochemical conditions prevailing in this area [8]. Firstly, these are the specific conditions of deep-water stagnant depressions of the closed-sea basin, which contributed to the accumulation of a thick stratum of finely dispersed pelitic sediments (with a pelitic fraction content of more than 90\%) enriched in organic matter, iron, sulfates, and carbonates. Secondly, this is the presence of high concentrations of hydrogen sulfide and methane in the bottom layers of the water column and the bottom sediments of the Derbent and South Caspian basins [39]. The latter results in reducing conditions forming already in the upper layers of bottom sediments. It is assumed that the total amount of pyrite that may form in sediments at the stage of early diagenesis is limited by the rate of input of decomposable organic matter, dissolved sulfate, and iron minerals. As it is known, the abundance of organic matter in sediments allows the development of sulfate-reducing bacteria, which reduce seawater sulfates and release hydrogen sulfide. The hydrogen sulfide then reacts with mobile iron, which ultimately leads to the formation of pyrite [65].

In the studied bottom sediments, framboidal pyrite is found in small quantities, although this mineral is an important indicator of the reduction zone of diagenesis. Its presence in the uppermost layer of sediments (in the South Caspian Basin, in the fluffy layer) testifies to the specificity of diagenetic processes under conditions of hydrogen sulfide contamination of the bottom layer of deep-water basins. According to geochemical data, no significant dependence of pyrite amount is found on the maximum contents of iron and organic matter. It can be assumed that the formation of pyrite is regulated by the presence or absence of a certain amount of sulfur in the pore waters of sediments. A significant amount of gypsum containing sulfur indicates a fairly high sulfur content in the sediments. The relationship between the content of gypsum and pyrite in the sediments 
was not traced. Therefore, it can be assumed that the formation of framboidal pyrite is regulated not by a certain content of sulfur or iron, but by bacterial activity.

The content of $\mathrm{C}_{\text {org }}$ in the bottom sediments of the Derbent and South Caspian basins is very high, especially in the upper layer, which provides favorable conditions for microorganisms, reaching high numbers here: in the Derbent Basin, 165/520 $\times 10^{6} \mathrm{cells} \mathrm{cm}^{-3}$ in the silty deposit layer; in the South Caspian Basin, 150/180 $\times 10^{6}$ cells $\mathrm{cm}^{-3}$ in the

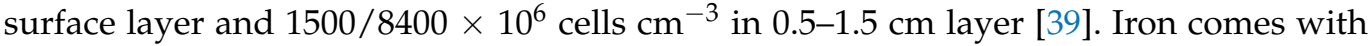
terrigenous runoff from the surrounding land, partly with aeolian material, and possibly with the hydrothermal waters of Cheleken Peninsula [33-35]. The high sulfate content in pore waters was noted earlier.

The aridity of the climate and the absence of runoff from the Caspian Sea leads to the concentration in bottom sediments of all components entering the South Caspian Basin. The subsequent transformation of bottom sediments in the process of diagenetic phase differentiation of matter under the influence of hydrogen sulfide contamination leads to the formation of specific associations of authigenic minerals. However, these mineral associations differ from the mineral associations of the Derbent Basin, in which sedimentation and diagenesis also take place under the influence of hydrogen sulfide contamination, but under different geographic, geological, and hydrological conditions.

\subsection{Associations of Authigenic Minerals in Bottom Sediments of Deep-Water Basins of the Caspian Sea}

Analysis of the distribution of authigenic minerals in the studied bottom sediments of the Caspian Sea makes it possible to distinguish different associations of authigenic minerals for each of the deep-water basins. These are mineral associations characteristic of the uppermost part of the sediments (interval $0-3 \mathrm{~cm}$ ) and underlying sediments. Primary methodological limitations, such as the asynchrony of data over intervals in different basins and different column powers, do not allow for a more detailed selection. Additional arguments for identifying the lower boundary of the upper interval were obtained as a result of the analysis of data from geochemical studies.

Thus, in the Derbent Basin, in sediments of the 3-46 cm interval, an authigenic association is formed from gypsum, calcite, magnesian calcite, siderite, and framboidal pyrite. The upper boundary of the interval is distinguished by the disappearance of such authigenic minerals as siderite and framboidal pyrite in sediments. An association of such authigenic minerals as gypsum and calcite is formed in sediments of the $0-3 \mathrm{~cm}$ interval. According to geochemical data, the sediments of this interval are characterized by maximum $\mathrm{C}_{\text {org }}$ contents.

In the South Caspian Basin, in sediments of the 3-35 cm interval, an association of such authigenic minerals as gypsum, halite, calcite, magnesian calcite, and framboidal pyrite is formed. The upper boundary of the interval is distinguished by the appearance of kutnohorite in the sediments. The association of such authigenic minerals as gypsum, halite, calcite, magnesian calcite, kutnohorite, and framboidal pyrite is characteristic of sediments of the $0-3 \mathrm{~cm}$ interval. According to geochemical data, the bottom sediments of this interval contain the maximum concentrations of $\mathrm{C}_{\text {org }}$ and $\mathrm{Mn}$.

A comparative analysis of the qualitative and quantitative composition of associations of authigenic minerals in different intervals of bottom sediments of each basin shows the change in the processes of authigenic mineral formation over time.

The most contrasting are the compositions of authigenic associations in the uppermost layer of bottom sediments of the Derbent and South Caspian basins. Judging by the higher total content of authigenic minerals and a more diverse mineral composition, the intensity of authigenic mineral formation during the period of accumulation of this layer of sediments in the South Caspian Basin is much higher than in the Derbent Basin. The very high contents of halite and gypsum, in our opinion, clearly indicate more arid sedimentation conditions in the southern part of the Caspian Sea. 
The associations of authigenic minerals in the sediments of different basins are various, indicating differences in the conditions of sedimentation and diagenesis, despite the fact that the water column and bottom sediments of both basins contain high concentrations of hydrogen sulfide and a high content of $C_{\text {org }}$.

We consider the aridity of the climate in the South Caspian region to be the main factor that determines the appearance of such differences in the uppermost layer of sediments of the basins. Judging by the changes in the composition of authigenic associations over time, the aridity in the South Caspian region increased sharply by the time of the accumulation of the upper layer (interval 0-3 cm).

Another feature of sedimentation and diagenetic processes in the South Caspian Basin is the effect of the discharge of hydrothermal waters near the Cheleken Peninsula and emissions of mud volcanoes. It is these sources that could cause the accumulation of high contents of barium and manganese in the sediments. Furthermore, subsequent diagenetic transformations led to the formation of authigenic minerals such as barite and kutnohorite.

\section{Conclusions}

As a result of the comprehensive lithological, mineralogical, and geochemical studies in the bottom sediments of the Derbent and South Caspian basins, it was possible to establish numerous manifestations of authigenic mineral formation, confined to the stage of early diagenesis. Authigenic minerals are represented by sulfates (gypsum, barite), chlorides (halite), carbonates (calcite, Mg-calcite, siderite, dolomite, kutnohorite), and sulfides (framboidal pyrite). Carbonates and sulfates are the predominant authigenic minerals in the deep basins of the Caspian Sea. The formation of authigenic gypsum is observed in all studied layers of sediments in the Derbent Basin and the South Caspian Basin. Calcite and $\mathrm{Mg}$-calcite are the most common minerals of the carbonate group; dolomite, siderite, and kutnohorite are found in smaller quantities. Gypsum and calcite, represented by a large number of different forms, accumulate in the bottom sediments of the South Caspian depression, which is characterized by an arid climate. Framboidal pyrite is formed both in the uppermost layers of the sediment (fluffy layer), due to the presence of hydrogen sulfide pollution, and in deeper layers, where the processes of reductive sub-water diagenesis take place.

It has been established that hydrogen sulfide contamination recorded in the bottom layer of the water column of the deep-water basins of the Caspian Sea can affect the formation of authigenic sulfides (framboidal pyrite), sulfates (gypsum), and carbonates (calcite, siderite, and kutnohorite), which are related to the activity of sulfate-reducing bacteria under reducing conditions.

It was revealed that specific associations of authigenic minerals in the bottom sediments of the Derbent and South Caspian basins are the product of the interaction of hydrological, biogeochemical, and sedimentation-diagenetic processes. The anaerobic oxidation of methane in combination with bacterial sulfate reduction are key biogeochemical processes occurring in the bottom sediments of these areas. Both processes control the formation of specific authigenic mineralization.

Author Contributions: Conceptualization, N.K. and L.R.; Methodology, N.K. and L.R.; Software, N.K. and L.R.; Validation, N.K. and L.R.; Analytical Studies, N.K., L.R. and O.D.; Investigation, N.K. and L.R.; Resources, N.K.; Data Curation, N.K. and L.R.; Writing-Original Draft Preparation, N.K.; Writing-Review and Editing, N.K. and L.R.; Visualization, N.K. and L.R.; Funding Acquisition, N.K. All authors have read and agreed to the published version of the manuscript.

Funding: Preparation and processing of samples, lithological-mineralogical and geochemical studies, as well as interpretation of the obtained data were supported by the Russian Science Foundation, grant no. 19-77-00015. X-ray diffractometry was performed within the framework of the State Assignment for Institute of Oceanology RAS (theme no. 0128-2021-0006) 


\begin{abstract}
Acknowledgments: The authors are grateful to the colleagues from the P.P. Shirshov Institute of Oceanology for their support. Special thanks go to A.K. Ambrosimov, A.A. Klyuvitkin, M.D. Kravchishina, N.V. Politova, A.N. Novigatsky and V.V. Gordeev for invaluable help, to L.V. Demina for $C_{\text {org }}$ and $C_{\text {total }}$ measurements, and to V.A. Karlov and M.A. Kovalev for assistance in performing scanning electron microscopy.
\end{abstract}

Conflicts of Interest: The authors declare no conflict of interest.

\title{
References
}

1. Larsen, G.; Chilingar, D. (Eds.) Diagenesis and Catagenesis of Sedimentary Formations; Mir: Moscow, Russia, 1971; p. 463. (In Russian)

2. Yapaskurt, O.V. Genetic Mineralogy and Stadial Analysis of Sedimentary Rock and Ore Formation Processes; Textbook; ESLAN: Moscow, Russia, 2008; p. 356. (In Russian)

3. Kalkowsky, E. Über die Erforschung der archaeischen Formationen, Neues Jahrb. Min. Geol. Palaeont. Monatsh 1880, 1, 1-29.

4. Strakhov, N.M. Selected Works. General Problems of Geology, Lithology and Geochemistry; Nauka: Moscow, Russia, 1983 ; p. 640. (In Russian)

5. Strakhov, N.M. Fundamentals of the Lithogenesis Theory; Academy of Sciences of the USSR: Moscow, Russia, 1960.

6. Glenn, C.R.; Filippelli, G.M. Authigenic mineral formation in the marine environment: Pathways, processes and products. Deep. Sea Res. Part II Top. Stud. Oceanogr. 2007, 54, 1141-1146. [CrossRef]

7. Lein, A.Y.; Ivanov, M.V. Biogeochemical Cycle of Methane in the Ocean; Nauka: Moscow, Russia, 2009; p. 576. (In Russian)

8. Kozina, N.; Reykhard, L.; Dara, O.; Gordeev, V. Framboidal pyrite formation in the bottom sediments of the South Caspian Basin under conditions of hydrogen sulfide contamination. Russ. J. Earth Sci. 2018, 18, 1-10. [CrossRef]

9. Kozina, N.V.; Reykhard, L.Y.; Dara, O.M.; Gordeev, V.V. Characteristic property of the formation of authogenic minerals in bottom sediments of the South Caspian Basin under conditions of hydrogen sulfide contamination. Oceanology 2021. in print.

10. Kravchishina, M.D.; Lein, A.Y.; Reykhard, L.E.; Dara, O.M.; Flint, M.V.; Savvichev, A.S. Authigenic Mg-calcite at a cold methane seep site in the Laptev Sea. Oceanology 2017, 57, 174-191. [CrossRef]

11. Glenn, C.R.; Prévôt-Lucas, L.; Lucas, J. (Eds.) Marine Authigenesis: From Global to Microbial; Special Publication No. 66; SEPM (Society for Sedimentary Geology): Tulsa, OK, USA, 2000; 525p.

12. Reykhard, L.Y. Pyrite framboid in bottom sediments of the White Sea. In Materials of the Annual Meeting of the Russian Mineralogical Society; Russian Mineralogical Society: Saint Petersburg, Russia, 2014; pp. 62-64. (In Russian)

13. Lein, A.Y. Authigenic Carbonate Formation in the Ocean. Lithol. Miner. Resour. 2004, 39, 1-30. [CrossRef]

14. Lein, A.Y.; Galchenko, V.V.; Pokrovsky, B.G. Marine carbonate nodules as a result of microbial oxidation of methane gas hydrate in the Sea of Okhotsk. Geochemistry 1989, 10, 1396-1406.

15. Astakhova, N.V. Autigenic carbonates in Upper Pleistocene-Holocene sediments of marginal seas of the northwestern Pacific Ocean. Pac. Geol. 1999, 18, 41-49. (In Russian)

16. Astakhova, N.V.; Nervov, G.A.; Yakusheva, I.N. Carbonate-barite mineralization in the Deryugin Depression (Sea of Okhotsk). Pac. Geol. 1990, 3, 37-42. (In Russian)

17. Krylov, A.A.; Khlystov, O.M.; Hachikubo, A.; Minami, H.; Zemskaya, T.; Logvina, E.A.; Lomakina, A.V.; Semenov, P.B. The reconstruction of the mechanisms of problematic authigenic carbonates formation in diagenetic and catagenetic environments associated with the generation/oxidation of hydrocarbons. Limnol. Freshw. Biol. 2020, 4, 928-930. [CrossRef]

18. Krylov, A.; Khlystov, O.; Zemskaya, T.; Minami, H.; Hachikubo, A.; Kida, M.; Shoji, H.; Naudts, L.; Poort, J.; Pogodaeva, T.P. First discovery and formation process of authigenic siderite from gas hydrate-bearing mud volcanoes in fresh water: Lake Baikal, eastern Siberia. Geophys. Res. Lett. 2008, 35, 05405. [CrossRef]

19. Derkachev, A.N.; Nikolaeva, N.A. Features of authigenic mineralogy in the sediments of the Sea of Okhotsk. In Far Eastern Seas of Russia; Akulichev, V.A., Ed.; Book 3 Geological and Geophysical Research; Nauka: Moscow, Russia, 2007; pp. $223-239$. (In Russian)

20. Kravchishina, M.D.; Lein, A.Y.; Flint, M.V.; Baranov, B.V.; Miroshnikov, A.Y.; Dubinina, E.O.; Dara, O.M.; Boev, A.G.; Savvichev, A.S. Methane-Derived Authigenic Carbonates on the Seafloor of the Laptev Sea Shelf. Front. Mar. Sci. 2021, 8, 690304. [CrossRef]

21. Astakhova, N.V.; Lipkina, M.I.; Melnichenko, Y.I. Hydrothermal barite mineralization in the Deryugin depression of the Sea of Okhotsk. Dokl. Earth Sci. 1987, 295, 212-215.

22. Derkachev, A.N.; Nikolaeva, N.A.; Mozherovskiy, A.V.; Baranov, B.V.; Barinov, N.N.; Minami, H.; Hachikubo, A.; Shoji, H. Manifestation of carbonate-barite mineralization around methane seeps in the Sea of Okhotsk (the western slope of the Kuril Basin). Oceanology 2015, 55, 390-399. [CrossRef]

23. The Caspian Sea. Moscow; USSR Publishers MSU: Moscow, Russia, 1969; p. 264. (In Russian)

24. The Caspian Sea: Problems of Sedimentogenesis; Nauka: Moscow, Russia, 1989; p. 184. (In Russian)

25. Lebedev, L.I.; Mayev, E.G.; Bordovsky, O.K.; Kulakova, L.S. Bottom Sediments of the Caspian Sea; Nauka: Moscow, Russia, 1973; p. 188. (In Russian)

26. Khrustalev, Y.P. Regularities of Sedimentation in the Intracontinental Seas of the Arid Zone; Nauka: Saint Petersburg, Russia, 1989; p. 261. (In Russian) 
27. Ambrosimov, A.K.; Klyuvitkin, A.A.; Kozina, N.V.; Kravchishina, M.D.; Libina, N.V.; Filippov, A.S.; Artamonova, K.V.; Torgunova, N.I.; Baranov, V.I.; Pol'kin, V.V. Complex studies of the Caspian Sea during the 41-st cruise of the R/V Rift. Oceanology 2014, 54, 671-676. [CrossRef]

28. Ambrosimov, A.K.; Klyuvitkin, A.A.; Goldin, Y.A.; Kravchishina, M.D.; Mutovkin, A.D.; Novigatsky, A.N.; Politova, N.V.; Zakharova, E.E.; Savvichev, A.S.; Korzh, A.O.; et al. Multidisciplinary studies of the Caspian Sea system during cruise 39 of the R/V Rift. Oceanology 2014, 54, 395-399. [CrossRef]

29. Ambrosimov, A.K.; Klyuvitkina, A.A.; Filippov, A.S.; Kozina, N.V.; Nemirovskaya, I.A.; Zolotykh, E.O.; Bud'ko, D.F.; Serebrennikova, E.A.; Bondar', A.V. Study of the north and central Caspian on the October 2015 expedition of the R/F Nikifor Shurekov. Oceanology 2017, 57, 756-758. [CrossRef]

30. Ambrosimov, A.K.; Klyuvitkin, A.A.; Filippov, A.S.; Korch, A.O. Multidisciplinary studies of the Caspian Sea System during the cruise of the R/V Tantal in May 2015. Oceanology 2017, 56, 757-759. [CrossRef]

31. Klyuvitkin, A.A.; Ambrosimov, A.K.; Kravchishina, M.D.; Kozina, N.V.; Budko, D.F.; Dukhova, L.A.; Serebrennikova, E.A.; Korzh, A.O. Comprehensive study of the Caspian Sea system during the second cruise of the Research Vessel Nikifor Shurekov. Oceanology 2015, 55, 311-314. [CrossRef]

32. Lein, A.Y.; Lisitzin, A.P.; Kravchishina, M.D.; Kozina, N.V.; Dara, O.M. Modern sedimentation: Sedimentogenesis and early diagenesis. In The System of the Caspian Sea; Nauchnyi Mir: Moscow, Russia, 2016; pp. 303-399. (In Russian)

33. Lukashin, V.N.; Kravchishina, M.D.; Klyuvitkin, A.A.; Kozina, N.V.; Novigatsky, A.N.; Politova, N.V. Suspended matter. In The System of the Caspian Sea; Nauchnyi Mir: Moscow, Russia, 2016; pp. 213-302. (In Russian)

34. Lisitzin, A.P.; Lukashin, V.N. Composition of dispersed sedimentary matter and fluxes in the water column of the Caspian Sea Dokl. Earth Sci. 2015, 464, 956-962. [CrossRef]

35. Lukashin, V.N.; Lisitzin, A.P.; Dara, O.M.; Kozina, N.V.; Klyuvitkin, A.A.; Novigatsky, A.N. Mineral composition of sedimentary matter in the Caspian Sea. Oceanology 2016, 6, 852-862. [CrossRef]

36. Lukashin, V.N.; Lisitzin, A.P. Geochemistry of dispersed sedimentary matter and its fluxes in the water column Caspian Sea. Oceanology 2016, 56, 675-689. [CrossRef]

37. Ivanov, M.V.; Savvichev, A.S.; Klyuvitkin, A.A.; Zakharova, E.E.; Rusanov, I.I.; Lein, A.Y.; Lisitsyn, A.P.; Chul'tsova, A.L. Resumption of hydrogen sulfide contamination of the water column of deep basin in the Caspian Sea. Dokl. Earth Sci. 2013, 453, 1094-1099. [CrossRef]

38. Kozina, N.V.; Lein, A.Y.; Dara, O.M. Unknown biomorphic structures-Environmental formations or laboratory artifact? Priroda 2016, 4, 70-73. (In Russian)

39. Lein, A.Y.; Savvichev, A.S.; Kravchishina, M.D.; Kozina, N.V.; Peresypkin, V.I.; Zakharova, E.E.; Veslopolova, E.F.; Mitskevich, I.N.; Shul'ga, N.A.; Lobus, N.V.; et al. Microbiological and biogeochemical properties of the Caspian Sea sediments and water column. Microbiology 2014, 83, 648-660. [CrossRef]

40. Gordeev, V.V.; Kozina, N.V.; Baturin, G.N. Distribution of metals (Cu, Zn, Ni, Co, Cr, Pb, Fe and Mn) in surface layer of bottom sediments of the Central and Southern Caspian region. Okeanol. Issled. 2019, 47, 26-51.

41. Maslov, A.V.; Ronkin, Y.L.; Kozina, N.V.; Klyuvitkin, A.A.; Novigatskii, A.N.; Filippov, A.S.; Shevchenko, V.P.; Kovach, V.P. Rare-earth element distribution and 87Sr/86Sr systematics in modern bottom sediments of the Caspian Sea. Dokl. Earth Sci. 2014, 459, 1418-1422. [CrossRef]

42. Maslov, A.V.; Kozina, N.V.; Klyuvitkin, A.A.; Novigatsky, A.N.; Filippov, A.S.; Shevchenko, V.P. Disrtibution of some rare and trace elements in modern bottom sediments of the Caspian Sea. Oceanology 2016, 56, 552-563. [CrossRef]

43. Maslov, A.V.; Kozina, N.V.; Shevchenko, V.P.; Klyuvitkin, A.A.; Sapozhnikov, P.V.; Zavialov, P.O. REE systematics in modern bottom sediments of the Caspian Sea and river Deltas worldwide: Experience of comparison. Dokl. Earth Sci. 2017, 475, 797-802. [CrossRef]

44. Dara, O.M.; Lein, A.Y.; Kozina, N.V.; Ivanov, M.V. First find of kutnohorite in modern sediments of the Caspian basin. Dokl. Earth Sci. 2015, 465, 1257-1261. [CrossRef]

45. Kozina, N.V.; Novigatsky, A.N. Composition of fragmental minerals of the surface layer of bottom sediments in the Caspian Sea. Oceanology 2014, 54, 348-364. [CrossRef]

46. Kozina, N.V. Carbonate accumulation in the Southern Caspian Sea. J. Comput. Theor. Nanosci. 2019, 16, 134-139. [CrossRef]

47. Sapozhnikov, V.V.; Grashchenkova, O.K.; Kivva, K.K.; Azarenko, A.V. Hydrological and hydrochemical studies of the middle and south Caspian Seafrom the R/V Issledovatel' Kaspia (September 2-17, 2006). Oceanology 2007, 47, 290-293. [CrossRef]

48. Lebedev, S.A.; Kostianoy, A.G. Satellite Altimetry of the Caspian Sea; Publishing Center OCEAN of the International Ocean Institute: Moscow, Russia, 2005; p. 366.

49. Reykhard, L.; Kozina, N.; Dara, O.; Shulga, N. Authigenic barite in the bottom sediments of the seas and oceans: Crystal morphology, composition, indicator properties. Abstract Collection Book. In Proceedings of the 6th World Multidisciplinary Earth Sciences Symposium WMESS 2020, Prague, Czech Republic, 7-11 September 2020; p. 161.

50. Reykhard, L.Y.; Kozina, N.V. Typomorphic features and indicator properties of the authigenic barite from bottom sediments of deep-water basins of the Caspian and Black seas. In Proceedings of the XXIV International Scientific conference (School) on Marine Geology, IO RAS, Moscow, Russia; 2021; pp. 278-281. (In Russian) 
51. Kozina, N.V.; Reykhard, L.Y.; Dara, O.M.; Starodymova, D.P.; Kochenkova, A.I. Features of authigenic mineral formations in Holocene bottom sediments of deep-sea depressions of the Black and Caspian Seas in areas of hydrogen sulfide contamination. In The Collection: Proceedings of the IX International Scientific and Practical Conference "Marine Research and Education (MARESEDU2020)"; OOO «PoliPRESS» Collection: Moscow, Russia, 2020; pp. 115-117. (In Russian)

52. Reykhard, L.Y.; Shulga, N.A.; Kozina, N.V.; Novichkova, E.A.; Dara, O.M.; Boev, A.G. Biominerals in aquatic geosystems under extreme conditions. In Proceedings of the BIOMIN XV: 15th International Symposium on Biomineralization, Munich, Germany, 9-13 September 2019; p. 104.

53. Bezrukov, P.L.; Lisitzin, A.P. Classification of bottom sediments in modern basins. Proceed. Inst. Oceanol. USSR Acad. Sci. 1960, 32, 3-14. (In Russian)

54. Brown, G. (Ed.) X-ray Methods of Studying and Structure of Clay Minerals; Mir.: Moscow, Russia, 1965; 600p.

55. Moore, D.M.; Reynolds, R.C. X-ray Diffraction and the Identification and Analysis of Clay Minerals, 2nd ed.; Oxford University Press: New York, NY, USA, 1997; 380p.

56. Biscaye, P.E. Mineralogy and sedimentation of recent deep sea clay in the Atlantic Ocean and adjacent seas and oceans. Geol. Soc. Am. Bull. 1965, 76, 803-832. [CrossRef]

57. Shlykov, V.G. X-ray Analysis of Dispersed Soils; M. GEOS.: Moscow, Russia, 2006; 176p. (In Russian)

58. Jørgensen, B.B.; Kasten, S. Sulfur cycling and methane oxidation. In Marine Geochemistry; Schulz, H.D., Zabel, M., Eds.; Springer: Berlin/Heidelberg, Germany, 2006; pp. 271-309.

59. Jørgensen, B.B.; Findlay, A.J.; Pellerin, A. The Biogeochemical Sulfur Cycle of Marine Sediments. Front. Microbiol. 2019, 10, 849. [CrossRef]

60. Volkov, I.I. Geochemistry of Sulfur in Ocean Sediments; Nauka: Moscow, Russia, 1984; 272p. (In Russian)

61. Mahmoudi, N.; Robeson, M.S.; Castro, H.F.; Fortney, J.L.; Techtmann, S.M.; Joyner, D.C. Microbial community composition and diversity in Caspian Sea sediments. FEMS Microbiol. Ecol. 2015, 91, 1-11. [CrossRef]

62. Hoffmann, T.D.; Reeksting, B.J.; Gebhard, S. Bacteria-induced mineral precipitation: A mechanistic review. Microbiology 2021, 167, 4 [CrossRef]

63. Paytan, A.; Griffith, E.M. Marine barite: Recorder of variations in ocean export productivity. Deep-Sea Res. II 2007, 54, 687-705. [CrossRef]

64. Reykhard, L.Y.; Kozina, N.V.; Dara, O.M.; Boev, A.G.; Novichkova, E.A.; Shulga, N.A.; Reykhard, A.G. Application of complex microscopic studies for solution of urgent problems of oceanology and marine geology. In Proceedings of the IX International Scientific-Practical Conf. Marine Studies and Education (MARESEDU-2020), Moscow, Russia, 26-30 October 2020; Volume 3, pp. 91-94. (In Russian)

65. Ocean Chemistry. Geochemistry of bottom sediments. In Oceanology Series; Nauka: Moscow, Russia, 1979 ; Volume 2, p. 536. (In Russian) 